\title{
ДОСЛІДЖЕННЯ ПОНЯТТЯ «ГАРМОНІЯ» В АСПЕКТІ ЖИТТЕВИХ СМИСЛІВ ОСОБИСТОСТІ
}

УдК:159.923.32/.37

\section{Гурлева Тетяна Степанівна}

Кандидат психологічних наук, стариий науковий співробітник лабораторії консультативної психології та психотерапії Інституту психологіі імені Г.С. Костюка, Національної академії педагогічних наук Украӥни, м. Київ (Украӥна)

ORCID ID: https://orcid.org/0000-0002-6518-5216

\begin{abstract}
Анотація. У статті здійснюється теоретичний аналіз поняття «гармонія» в аспекті життєвих смислів особистості, їх структури, ієрархї, динаміки, умов сходження на більи високий рівень. Зазначено, щуо у дослідженнях вітчизняних та зарубіжних вчених поняття гармонія здебільшого розглядається у контексті розвитку особистості взагалі, ї̈ стосунків $з$ іншими людьми, зі світом, але не охоплено смислове поле особистості як урівноважене иіле. Під «гармонією життєвих смислів» особистості автор розуміє таке співвідношення частин смислової сфери, яке характеризує внутрішньо несуперечливе, враховуючи ймовірні «смислові дисгармонї̈, існування життєвих смислів людини на певному етапі ї̈ становлення як тілесної, соичальної, духовної істоти. Акиентовано увагу на високих, сутнісних, духовних смислах, які забезпечують гармонію смислової сфери особистості, урівноважують, впорядковують потреби людини, забезпечують висхідний вектор їх розвитку. Показано наявність певної гармонії у відносній дисгармонійності життєвих смислів, які у своєму зв'язку і взаємовпливові сприяють благополучному розвитку особистості. Підкреслено значення гармонізації життєвих смислів у підлітковому та юнацькому віиі. 3 позииій гуманістичної психології окреслено перспективи психологічної допомоги особистості у гармонізащії життєвих смислів. Стверджується, що умовою усвідомлення, пошуку $i$ відкриття людиною смислу життя $i$ гармонізації смисложиттєвої сфери особистості є діалог, діалогічне спілкування між людьми.
\end{abstract}

Ключові слова: гармонія, смислова сфера особистості, гармонія життєвих смислів, смислова дисгармонія, особистісний розвиток по висхідній, суб'єкт, гармонізація, гуманізм, діалог.

Постановка проблеми. Сучасні соціотва у відродженні вищих людських цінностей культурні реалії загострили потребу суспільс- і смислів, в процесі реалізації яких людина 
відчуває себе суб'єктом життя. Видається важливим вивчення зовнішніх і внутрішніх чинників гармонізації смислової сфери особистості з урахуванням структурних дисгармоній, характерних для певного віку, статі, обставин виховання і розвитку. Актуальною є розробка проблеми психотерапевтичних умов, зокрема діалогічних стосунків між партнерами по спілкуванню - психологом і клієнтом, 3 метою гармонізації смислової сфери особистості як суб'єкта життєдіяльності. У даній же статті приділено увагу розгляду категорії «гармонія» у контексті життєвих смислів особистості, у становленні іiі цілісності, врівноваженості і досконалості.

Аналіз останніх досліджень і публікацій. У наукових джерелах поняття гармонія i гармонійність здебільшого розглядається у контексті розвитку особистості, їі життя, стосунків із собою, з іншими людьми, зі світом. В роботах відомих вчених як далекого минулого (Діоген, Сковорода, Сократ, Спіноза та ін.), так і сучасності (О. Г. Асмолов, Г. О. Балл, О. Ф. Бондаренко, М. Й. Боришевський, Б. С. Братусь, М.С. Каган, 3. С. Карпенко, К. В. Карпінський, В. В. Клименко, О. П. Колісник, Д. О. Леонтьєв, О. М. Леонтьєв, А. Маслоу, В. О. Моляко, О. Л. Музика, Є.М. Осін, М. В. Савчин, С. Л. Рубінштейн, Н. В. Чепелєва, В. Е. Чудновський та ін.) чільне місце приділено смисловій сфері особистості, їі структурі, умовам певної узгодженості між окремими складовими. Смислова сфера розглядається як особливим чином організована динамічна ієрархічна структура або сукупність смислових структур і зв'язків між ними, що забезпечують смислову регуляцію життєдіяльності суб'єкта і забезпечують цілісність особистості. Зазначено провідна роль «вищих», «високих», «найголовніших», «замежових», «екзистенційних» смислів у процесі особистісного розвитку і вдосконалення людини, підвищення якості їі життя.

Вчені розрізняють також «структурні дисгармонії» (Г. О. Балл), які є нормальними у процесі становлення особистості, а також дисгармонію як «форму кризи» (Т. М. Титаренко), яка передує подальшому особистісному, духовному зростанню людини. Втім, достатньо не вивчені і не визначені специфіка, ознаки і межі гармонії смислової сфери особистості та відповідно до цього умови іiі гармонізації у різних вікових періодах. Існуючий термін «гармонія» не використовується задля того, щоб охопити смислову сферу особистості як диманічне, «живе» цілісне утворення, причому таке співвідношення його частин, яке характеризує несуперечливий, враховуючи імовірні «смислові дисгармонії», розвиток життєвих смислів людини на певному етапі іiї становлення як тілесної, соціальної, духовної істоти. Адже можна говорити про гармонійність, гармонійне поєднання життєвих смислів у підлітковому, юнацькому, зрілому тощо віці. 
Mema cmammi - здійснити теоретичний аналіз поняття гармонія, його співвіднесеність $з$ системою життєвих смислів людини; дати пояснення «гармонії життєвих смислів» $\mathrm{i}$ «смислових дисгармоній»; окреслити перспективи гармонізації життєвих смислів особистості.

Методи дослідження: теоретичний аналіз поняття гармонія у контексті системи життєвих смислів особистості; синтез і узагальнення отриманих даних.

Виклад основного матеріалу та результатів дослідження. Згідно сучасних уявлень, гармонія взагалі - це поєднання, злагодженість, взаємна відповідність якостей (предметів, явищ, частин цілого). Поняття «гармонія» відображає єдність і цілісність іiі елементів, навіть полярних, їх взаємо узгодженість і рівновагу.

В античній філософії поняття «гармонія» означало благозвучність, злагодженість, погодженість частин до єдиного цілого, завершеність. У Древній Греції поняття гармонія пов'язувалася 3 поняттями «згода», «злагода», «мирне співжиття», «організованість Всесвіту» [12 та ін.]. У Великому тлумачному словнику сучасної української мови гармонія порівнюється 3 самодостатністю особистості, оскільки всі сфери життя, такі як здоров'я, сім'я, кар'єра і бізнес, особистісний ріст, духовність перебувають у повному співзвуччі $з$ людиною. Це поняття доречно визначати і як «здоров'я», яке можна розуміти як «внутрішню цілісність, незіпсованість, відсутність внутрішньої порчі», за Д. М. Ушаковим. Гармонія - це не лише певний фізіологічний стан організму, а ще й психологічна рівновага та соціальне й духовне благополуччя людини, за Т. Ф. Сфремовою [див. 5, с. 93]. Визнано, що гармонія - це не застиглий стан, а неперервний процес, шлях до ідеалу, повноти, довершеності. Упорядковане (гармонізоване) особистісно-екзистенційне життя - то момент його відносної сталості, самототожності та ідентичності у безперервному потоці «абсолютного руху становлення» (Г. Гегель).

Протилежне гармонії - дисгармонія, розлад, безформність, колізія, хаотичність, неспільномірність предметів і явищ, які гальмують або руйнують процес досягнення результату, спотворюють дії та діяльність, призводять до втрати здоров'я душі і тіла людини. Дисгармонія особистості передбачає їі бездуховність, а результатом духовного розвитку $є$ актуалізація духовного потенціалу і досягнення внутрішньої гармонії особистості. Гармонійна особистість перебуває в єдності зі світом, людьми i самою собою. Вчений Г. О. Балл виділяє такі сторони гармонійності особи: взаємна відповідність ії підсистем (за О. Ф. Лазурським, «ендопсихіка» i «екзопсихіка»), і цілісність, яка знаходить яскравий вияв у «тісному, органічному зв'язку властивих даній людині здібностей, об'єднаних навколо одного спільного центра» - пов'- 
язаного найчастіше 3 «головною справою, ... основним завданням життя» цієї людини [1].

Рушійною силою розвитку системи (особи) є притаманні їй внутрішні суперечності, тобто, за Г. О. Баллом, «структурні дисгармонії», без яких особистість (система) не здатна до розвитку. Окрім того, на вищих рівнях свого розвитку людська істота, пише В. О. Татенко, знаходить можливість мимовільно порушувати нею ж встановлену рівновагу, народжувати із себе новий світ стосунків 3 іншими сущими і з самим собою, i, таким чином, крок за кроком перевершувати себе саму. Аутентичною для людини є можливість руху до нового, більш високого рівня єднання зі світом і самим собою [20]. Гармонія є єднання і злагода душі і тіла людини. Навпроти, дисгармонія (колізія, неузгодженість, «низьке, потворне, бридке»), зауважує В. В. Клименко, - «це стан людини, коли найціннішої властивості - гармонії - у неї вже бракує, вона існує із зруйнованою душею або дезорганізацією механізмів, яка тільки-но почалась. Якщо гармонія в людині є, вона іï досягла, то це гармонія не тільки тіла, його рухів, дій, а й гармонія душі - умова гармонії 3 довкіллям». У понятті гармонія, пише вчений, «неодмінно укладена напрямна роль; поняття гармонія задає мету й допомагає розуму ставити завдання, конструктивно розробляти шлях досягнення мети, а значить іти до гармонійного стану» [6, с. 38-39]. То ж, деструк- тив дисгармонії виражається у руйнівному, дестабілізуючому впливі на психічний і моральний стан людини, на траєкторію їі життєвого шляху.

Можна говорити, щ⿻о гармонія і дисгармонія мають як загальні риси, властиві всім людям, так і індивідуальні-характеризувати особистісний розвиток окремої людини, смислову наповненість ї̈ існування, виходячи з унікальної життєвої, екзистенційної ситуаиії.

Становлення гармонійно розвинутої людини пов'язане з формуванням ієрархічної, багаторівневої структури мотивів і цінностей: домінуванням вищих рівнів над нижчими. Piвень мотивів і цінностей, на думку М. Й. Варій, визначається мірою їхньої спільності, починаючи 3 особистих мотивів (найнижчих) через інтереси близьких людей, колективу, суспільства - до загальнолюдських універсальних цілей [3]. О. Ф. Лосєв відзначав, що головними прагненнями особистості є абсолютне самоствердження, внутрішня свобода, цілісність і гармонійність. «Вона бажає існувати так, як існують боги, що споглядають безкінечний світ і розумну тишу свого, ні від чого не залежного, світлого буття». I це існування стає можливим у любові, наголошує С. Д. Максименко [9], яка виступає гармонізуючим джерелом духовного, сущого, справжнього, людяного в людині. Вчений звертається до діалогів Платона, який зазначав: «Любов’ю називається прагнення цілісності і потяг до неї» [Там само]. У даному контексті доречно 
навести вислів Моріхея Уесіба: «Кожний Майстер, в усі часи і в усіх країнах, чув поклик і досягав гармонії з небом і землею. Багато стежок веде до вершини гори Фудзі, але ця вершина одна - любов».

Зміст смислової сфери як центрального, ядерного утворення особистості, визначає ставлення людини до навколишнього світу і самого себе, спрямованість і зміст соціальної активності, формує поведінку і вчинки, надає сенс і напрям життєдіяльності (К. О. Абульханова-Славська, Д. О. Леонтьєв, О. В. Москаленко, Г. В. Чайка та ін.). Рівень особистісного розвитку визначається рівнем духовноморальної свідомості й волі, що зумовлює моральний самоконтроль людини над власними психічними станами, вказує на напружену діяльність особистості, спрямовану на позитивну зміну своїх думок, почуттів, вчинків, на оволодіння вищим смислом людського життя (А. Я. Арет, М. Й. Боришевський, І. С. Булах, Е. О. Помиткін, С. О. Ставицька та ін.).

С. Л. Рубінштейн запропонував трьохрівневу структуру особистості: психофізіологічний (базовий рівень), індивідуальнопсихологічний та індивідуально-смисловий, який базується на смисложиттєвих цінностях і зрілих ставленнях особистості (до себе, до інших, до світу), що забезпечують підтримку стану внутрішньої рівноваги [17]. Саме індивідуально-смисловий рівень структури особистості є фундаментом, основою розвитку і функціонування особистості, яка прагне цілісно- сті, гармонії і довершеності. «Моє життя завжди йшло по висхідній...», - писав С. Л. Рубінштейн у своїх Щоденниках, стверджуючи висхідний вектор смислів і цінностей, які спрямовують мету особистості, урівноважують їі життя.

Урівноваження структурних компонентів особистості вказує на їі гармонійний розвиток, який тісно пов'язаний із творчістю. Адже здатність людини до функціонування на рівні життєтворчості визначає іiі особистісне (а саме - психічне, психологічне і духовне) здоров'я [14]. Формування гармонії відбувається творчим шля-хом, констатує Т. М. Титаренко [21]. Творчість є універсальним способом розвитку, який веде до всіх форм самовираження, вважає А. Маслоу [10]. У відомій праці «Деятельность. Сознание. Личность» О. М. Леонтьєв зазначив, що...особистість не може розвиватися у рамках споживання, іiі розвиток обов'язково передбачає зміщення потреб на творення, яке одне не знає меж».

Згадаймо міркування В. А. Петровського стосовно того, що «гармонія смислів... $\epsilon$ не більш ніж чудова казка» [15], і можна говорити про те, що гармонійна особистість це, за великим рахунком, - ідеал. Але у процесі безперервного, часто тернистого, особистісного розвитку у людини є прагнення і потреба долати супутні проблеми і досягати певної узгодженості, урівноваженості та єдності усіх сторін свого людського єства, свого «Я», йти до творчих висот, духовної краси і досконало- 
сті. Як висловився Л. В. Ушкалов: «Вийти і прямувати до Абсолюту, а, отже, до самих себе справжніх» [22].

Дослідники екзистенційно-гуманістичної напрямку у психології (Д. О. Леонтьєв, I. С. Кон, К. Роджерс, С. Л. Рубінштейн та ін.) визнають концепцію становлення, згідно якої особистість весь час перебуває у процесі розвитку і шукає сутнісного, прагне довершеності. Однією з найважливіших потреб особистості, є потреба у смислі свого існування [7, c. 208-209]. В. Франкл вважає, що питання про смисл життя є найлюдянішим 3 усіх питань, адже уже сама його постановка свідчить про опікуваність людиною духовною стороною життя [23]. 3 позицій духовної парадигми М. В. Савчин стверджує, що «у внутрішньому світі людини духовна сила породжує синергетичні тенденції та блокує ентропійні, запобігає порушенню гармонії між психологічною, соціальною, моральною та духовною автентичностями особистості. У точках біфуркації (ситуаціях криз функціонування та розвитку) вона $є$ своєрідним атрактором, що визначає напрям розвитку особистості, сприяє розв'язанню нею зовнішніх та внутрішніх суперечностей та зумовлює іiі правильні життєві та ситуативні вибори [19, с. 45].

Логічно думати, що підпорядкування смислів, за В. Е. Чудновським, найголовнішому, найвищому смислу [24], веде до гармонізації смислової сфери особистості. Духовність як високе протиставляється низькому, гріхов- ному, аморальному. Духовний розвиток - це свідома самозміна людини, яка починається «з пошуку нових смислів, які перетворюють систему ставлень до себе і до світу» $[13$, с. 86]. В. Е. Чудновський розглядає «гармонійну структуру смисложиттєвих орієнтацій», що визначає максимальне розкриття здібностей людини, iї емоційний комфорт, який проявляється у переживанні повноти життя і задоволеності ним [13]. Натомість «неоптимальний», «помилковий», «конфліктний», «бездуховний» смисл життя $є$ джерелом кризи у розвитку особистості, деструктиву, неблагополуччя, деформацій і різноманітних розладів (А. Адлер, К. В. Карпінський, Г. Рікер, В. Е. Чудновський, Т. Шнель та ін.).

Слід підкреслити, що сучасна людина потребує відкриття та реалізації не будь-яких, а саме сутнісних, буттєвих смислів, прагне відчувати і виявляти себе суб'єктом життя, особистістю, відповідальною, креативною, зрілою, вільною, духовною, спроможною піднесено переживати пошук і творення власної сутності, свого неповторного, унікального, емоційно багатого життєвого шляху. Згадаймо С. Л. Рубінштейна, для якого смисл життя - це ціннісно-емоційне утворення особистості, котре проявляється у саморозвитку, самореалізації особистісних якостей суб'єкта, що шукає і знаходить вищий, «замежовий» смисл свого буття. Учений пояснює, що «смисл людського життя - бути джерелом світла і тепла для інших людей. Бути свідомістю Всесвіту і со- 
вістю людства. Бути центром перетворення стихійних сил у сили свідомі. Бути перетворювачем життя, викорчовувати з нього всяку скверну $i$ безперервно вдосконалювати жит$m я \gg[18$, c. 113$]$.

Наявність такого смислу, або таких, за нашим визначенням, «високих смислів» (або «духовного смислового ядра») як Любов, Совість, Гідність, Честь, Відповідальність, Творчість та ін. [4] - ознака того, що людина є особистістю, яка здатна до постійного саморозвитку і самотворення, пошуку нових граней власного існування. Така особистість сама відчуває в собі і є, згідно цитати С. Л. Рубінштейна (див. вище), транслятором світла, тепла, совісті, свідомих сил, спрямованих на перетворення і вдосконалення життя, досягнення щастя.

Найбільш осмислене життя є більш щасливим, «найкращим» - подібної думки дотримувались такі великі філософи, як Сократ, Декарт, Спіноза, Діоген. Реалізація серцем відкритого смислу приносить людині задоволення своїм існуванням, справжнє щастя. Древньогрецький філософ Платон вважав, що життя має бути осмисленим, що сутністю усілякої доброчинності є знання того, що треба робити і чого не можна робити, що природа людини визначається іiі душею, точніше, душею і тілом, але з приматом душі над тілом, божественного безсмертного начала над смертним, тілесним. Він закликав до пошуку істини, яка прихована в самій людині, і яку слід лише віднайти. Про світло і красу, які слід відкрити у собі, як основу справжнього людського щастя, писав Григорій Сковорода у збірці «Сад пісень»: «Шукаємо щастя по країнах, століттях, а воно скрізь і завжди з нами; як риба в воді, так і ми в ньому, і воно біля нас шукає нас самих. Нема його ніде від того, що воно скрізь. Воно схоже до сонячного сяйва відхили лише вхід у душу свою» (виділено нами - Г. Т.). Сучасні вчені також вважають, що без наявності смислу та його успішної реалізації щастя неможливе [11; 16 та ін.].

Дослідники становлення смислової сфери особистості зауважують саме на підлітковому і юнацькому віці, оскільки саме у ці вікові періоди юна особистість найбільш відкрита до сприйняття смисложиттєвих понять, прагне самостійно відшукати і творчо реалізувати власні життєві смисли, відкриває нові, переосмислюючи вже набуті цінності і смисли. У підлітковому і особливо юнацькому віці формується готовність до особистісного та життєвого самовизначення, професійного самопроектування (О.О.Бодальов, Г. О. Вайзер, О. О. Зарецька, I. С. Кон, С. Д. Максименко, В. О. Моляко, О. Л. Музика, М. Л. Смульсон, Ю. М. Швалб та ін.).

Саме тоді постає питання якості смислу життя, його вивищення, знаходження гармонії між нижчими потребами і духовними здатностями людини. Важливим $\epsilon$ не лише розуміння значення «високого смислу», якого прагне людина, («Що то за смисл?», «Як його можна на- 
звати?»), а й емоційне ставлення до нього i готовність певним чином діяти, вчиняти. Не випадково, опитані нами юнаки, відповідаючи на запитання «Що значить для вас високий смисл? Що ви вкладаєте в це поняття?», зазначили: «це означає - любити людей», «чинити добро», «намагатися знайти своє місце у житті країни», «бути гідним», «високе надихає» тощо. Отже, юні респонденти підкреслюють дієвість, вчинковість смислу поряд з його змістовним наповненням та емоційним ставленням до нього. Окрім того, більшість опитаних вітчизняних психологів-консультантів і психотерапевтів екзистенційно-гуманістичного спрямування виявляють екзистенційні смисли, а також смисли самореалізації, когнітивні (за методикою В.Ю. Котлякова), що підтверджує їх змогу допомогти людині, яка цього потребує, у пошуку особистісного смислу життя. Анкетне опитування психологів показало, що провідним методом роботи з клієнтом у розв'язанні цієї екзистенційної проблеми $\epsilon$ «душевна» розмова, емпатійна бесіда, діалогічне спілкування. Психологічна допомога сприяє усвідомленню людиною своїх життєвих смислів, визначенню пріоритетності у власній системі смислів тілесної, соціальної чи духовної їі складової, їх співвіднесеності між собою [4].

У даній статті під «гармонією життевих смислів» особистості розуміється таке співвідношення частин смислової сфери, яке характеризує внутрішньо несуперечливий, враховуючи імовірні «смислові дисгармонії», існування життєвих смислів людини на певному етапі ії становлення як тілесної, соціальної, духовної істоти. Високі, сутнісні, духовні смисли забезпечують гармонію смислової сфери особистості, надають їй рівноваги, впорядковують і скеровують потреби людини, забезпечують висхідний вектор їх розвитку, «проливаючи світло» на всі інші прояви життєдіяльності особистості як суб'єкта.

Гармонія може існувати у відносній, несталій дисгармонійності життєвих смислів, які у своєму зв'язку і взаємовпливові сприяють благополучному, конструктивному розвитку особистості. Така тимчасова, плинна смислова дисгармонія $є$ перехідним етапом до стану гармонії смислової сфери особистості, яка перебуває у процесі неперервного розвитку по висхідній. Але смислова дисгармонія є деструктивною, коли гальмує розвиток особистості, не дозволяючи йому вийти на новий рівень, об'єднати життєві смисли в єдине, урівноважене ціле поле смислів. Деструктив може виявлятися у стійкому, без варіативних змін у відповідності до зовнішніх і внутрішнім умов життєдіяльності, порушенні співідношення між різними елементами смислової сфери: наприклад, перевага смислів власної кар'єри чи бізнесу над духовними, або нехтування власним здоров'ям заради самореалізації у соціумі. Це може стати причиною декструктивного переживання кризи, невротичних розладів та ін. Дисгармонія може визначатися також у по- 
рушенні між конгітивним (знання), емоційним (переживання) і поведінковий (або дієвим) складовими смислу (наприклад, людина прагне досягти досконалості і майстерності у певній справі, бо розуміє, що це підвищить якість іiі життя, але емоційно не готова до відповідального прийняття рішення, конкретних дієвих кроків для отримання омріяного результату).

У контексті даної статті важливо підкреслити значення атмосфери, того психологічного простору, завдяки якому і в якому стає можливим усвідомлення людиною власних життєвих смислів і відкриття нових та пошуку гармонії між різними рівнями смислової структури. У цьому сенсі поняття гармонії тісно пов'язане з поняттям гуманізму, а гармонізація з гуманізацією - стосунків, діяльності людини. Гармонізація стосунків особистості із внутрішнім, автентичним Я, вважають вітчизняні дослідники, є передумовами гуманізації будь-яких міжособистісних стосунків, що забезпечують конструктивні особистісні зміни, формування фундаментальних гуманістичних знань, умінь діалогічного спілкування [8, с.7].

Гуманізм заохочує на партнерську взаємодію людей та людських спільнот (Г.О. Балл), передбачає допомогу партнерам не лише у задоволенні їхніх дефіцитарних потреб, а й у їх долученні до переживання та реалізації буттєвих цінностей - добра, істини, краси, справедливості, досконалості тощо (А. Маслоу). У розвитку особистості провідну роль відіграє взаємозбагачувальний діалог між учасниками, зокрема психотерапевтичного процесу. 3 точки зору гуманістичної психології варто, пише Г.О. Балл, «по-перше, прагнути максимального розкриття конструктивних здатностей самого психолога як суб'єкта діяльності; по-друге, забезпечувати діалогічну, просякнуту повагою до партнера й налаштовану на розкриття і його конструктивних здатностей, взаємодію з ним...» [2, с. 23].

Діалог - це духовне спілкування, діяння, вчинок, що є сутнісним втіленням суб'єктної активності особистостей, це така суб'єктсуб'єктна взаємодія, коли одна людина активно розвається сама і сприяє розвиткові іншої людини (Г.В. Дьяконов, М.В. Папуча, В.О. Татенко та ін.). Пізнаючи себе, свої власні можливості і здатності, людина як суб'єкт життя відкриває все нові й нові резерви особистісного висхідного росту і самовдосконалення, зберігаючи і збагачуючи гармонію із самим собою, з іншими людьми, зі світом взагалі. В процесі діалогічної смислової взаємодії 3 іншим людина активно пізнає власні життєві цінності і смисли. В ході діалогу партнери по спілкуванню краще розуміють себе, один одного, навколишній світ, життя.

Висновки. У статті наголошено, що для сучасної людини питання пошуку смислу життя і гармонізації свого існування є вельми актуальним. Особистість потребує віднайдення для себе тих смислів, до яких вона прагне і які може втілити у реальність, забезпечивши розвиток себе як біологічної, соціальної і ду- 
ховної істоти, досягати гармонії всередині себе і у зовнішньому світі. Показано, що гармонія особистості - це не якийсь застиглий стан, а неперевний процес становлення, який відбувається через внутрішні суперечності, а також протиріччя з навколишнім середовищем, які поглиблюють або згладжують певні структурні дисгармонії.

Пропонуються визначення поняття «гармонія життєвих смислів», розуміння «смислової дисгармонії» особистості. Зазначено наявність гармонії у відносній дисгармонійності уже існуючих життєвих смислів, які у своєму динамічному зв'язку і взаємовпливові сприяють благополучному, конструктивному розвиткові особистості. У цьому сенсі важливо підкреслити значення гармонізації життевих смислів у підлітковому та юнацькому віці, коли $є$ визначальним становлення смислової сфери особистості як суб'єкта життєдіяльносTi.

3 позицій гуманістичної психології окреслено перспективи гармонізації смислів життя різного рівня - біологічного, соціального, духовного - у процесі психологічної допомоги людині. У статті акцентовано увагу на тому, що високі, сутнісні, духовні смисли забезпечують гармонію смислової сфери особистості, урівноважують, впорядковують потреби людини, забезпечують висхідний вектор їх розвитку. Стверджується, що умовою усвідомлення, пошуку і відкриття людиною смислу життя і гармонізації смисложиттєвої сфери особистості є діалог, діалогічне спілкування, діалогічна смислова взаємодія між людьми, зокрема психологом і окремою людиною, яка потребує психологічної допомоги у разі втрати смислу існування або смисложиттєвої дезорієнтації.

\section{Перспективу подальших досліджень} слід вбачати $y$ вивченні гармонії і дисгармонії на різних рівнях смислової структури особистості і між різними рівнями системи, а також розроблення питання діалогічних стосунків між партнерами по спілкуванню 3 метою гармонізації смислової сфери особистості як суб'єкта життєдіяльності.

\section{Перелік використаних джерел:}

1. Балл Г. О. Категорія гармонії в аналізі проблем освіти / Г.О. Балл // Педагогічна майстерність академіка Івана Зязюна: зб. наук. пр. / [редкол. Н.Г. Ничкало (голова), та ін. ; упоряд.: Н.Г. Ничкало, О.М. Боровік ; Ін-т пед. освіти і освіти дорослих НАПН України. К. : Богданова А.М., 2013. - С. 114-120.

2. Балл Г. Система принципів раціогуманізму / Георгій Балл // Психологія і суспільство. - 2011. - № 4. - С. 16 32.

3. Варій М. Й. Загальна психологія / М.Й Варій: Навчальний посібник / 2-ге видан., випр. і доп. - К.: «Центр учбової літератури», 2007. - 968 с.

4. Гурлєва Т. С. Високий смисл життя як цінність і чинник формування стратегій психологічної допомоги у вирішенні людиною екзистенційних проблем // Соціокультурні чинники становлення сучасної парадигми психотерапевтичної допомоги особистості: монографія / [З.Г. Кісарчук, Л.О. Гребінь, Т.С. Гурлєва та ін.] ; за ред. З.Г. Кісарчук. - Кіровоград: Імекс-ЛТД, 2012. С. $94-118$. 
5. Зазимко О. Формування життєвих цінностей у юнацькому віці: психологічні особливості / О. Зазимко // Вісн. Київ. нац. торг.-екон. ун-ту. - 2012. - № 4. - С. 89104.

6. Клименко В. В. Структура психофізіологічних станів у професійному здійсненні особистості / В.В. Клименко // Психофізіологічні закономірності професійного самоздійснення особистості : монографія / О.М. Кокун, В.В. Клименко, О.М. Корніяка. О.Р. Малхазов [та ін.] ; за ред.О.М. Кокуна. - Р.1.2. К.: Педагогічна думка, 2015. - С. 16-51.

7. Кон I. С. Психологія ранньої юності: Кн. для вчителя / І.С. Кон. - М.: Просвещение, 1989 . - 255 с. (Психол. наука - школі).

8. Кониептуальні засади психолого-педагогічної підготовки конкурентоздатного фахівця в умовах післядипломної педагогічної освіти : на вибірці науковопедагогічних працівників / автор.кол. : Л.М. Сергеєва, O.І. Бондарчук, М.І. Скрипник, А.О. Молчанова, О.А. Філь; наук. ред. Г.О. Козлакова. - К. : ДВНЗ «Унт менедж.освіти», 2015. - 40 с.

9. Максименко С. Д. Особистість починається з любові / С. Д. Максименко // Загальна психологія : хрестоматія : навч. посіб. для студ. вищ. навч. закл. / упоряд.: О.В. Скрипченко, Л.В. Долинська, 3.В. Огороднійчук та ін. - К. : Каравела, 2007. - С. 428-444.

10. Маслоу А. Мотивация и личность / А. Маслоу. 3-е изд. - СПб.: Питер, 2008. - 352 с. (Серия "Мастера психологии").

11. Осичнюк E. В. Смысл жизни... В чём он? / Ефим Вениаминович Осичнюк. - Киев: Знание, УССР, 1987. 47 с. (Серия 2).

12. Павлик Н. В. Психологія гармонізації характеру в юнацькому віці / Наталія Василівна Павлик. - Дис. д-ра психол.наук : 19.00.07 - педагогічна та вікова психологія. - Київ, 2017. - 527 с.

13. Пашукова Т. И. Изменение смысла жизни и духовное преобразование человека / Смысл жизни и акме : 10 лет поиска : в 2 ч. / Т И. Пашукова / под ред.
А.А. Бодалёва,
Г.А. Вайзер,
Н.А. Карповой,

В.Э. Чудновского. - М. : Смысл, 2004. - Часть 2. $224 \mathrm{c}$.

14. Психологія і педагогіка життєтворчості : навч.- метод. посіб. / за ред. Л.В. Сохань, І.Г. Срмакова. - К. : ВІПОЛ, 1996. - 792 с.

15. Психология с человеческим лицом: Гуманистическая перспектива в постсоветской психологии / Под ред. Д.А. Леонтьева, В.Г. Щур. - М.: «Смысл», 1997. - 335 с. - (Фундаментальная психология).

16. Рощчин Д. Г. Категорія "смисл життя особистості" в системі суміжних понять гуманітарних наук / Д.Г. Рощин // Вісник Київського нац. університету ім. Тараса Шевченка: сер: Соціологія . - 2010. - № 1/2 . C. 94-98.

17. Рубинштейн С. Л. Проблемы общей психологии / С.Л. Рубинштейн. - СПб. : Питер Ком, 1999. - 720 с.

18. Рубинштейн С. Л. Человек и мир / С.Л. Рубинштейн. - М.: Наука, 1997. - 190 с.

19. Савчин M. Теоретико-методологічна ресурсність духовної парадигми психології в дослідженні особистості / Мирослав Савчин // Психологія особистості. 2015. - № 1 (6). - С. 42-52.

20. Татенко B. A. Предмет и метод психологической науки: субъектная парадигма / В.А. Татенко // Предмет и метод психологии: Антология / Под ред. Е.Б. Старовойтенко. - М.: Академический Проект: Гаудеамус, 2005. - с.490-509.

21. Титаренко Т. М. Життєвий світ особистості: у межах і за межами буденності / Т.М. Титаренко. - К. : Либідь, 2003. - 374 с.

22. Ушкалов Л. Ловитва невловного птаха: життя Григорія Сковороди / Леонід Ушкалов. - К. : Дух і Літера, 2017. - 368 с. (Серія «Постаті культури»).

23. Франкл В. Человек в поисках смысла / Виктор Франкл. - М. : Прогресс, 1990. - 360 с.

24. Чудновский В. Э. Роль смысложизненных ориентаций и акме в профессиональной деятельности (опыт теоретико-эксперимент. исследования

В.Э. Чудновский, А.А. Бодалев, Г.А. Вайзер, 
Е.Е. Вахромов, Н.Л. Карпова, А.В. Суворов // Психологический журнал. - 2004. - Т. 25, № 1. - С. 25-30.

\section{References (Transliteration):}

1. Ball G. O. Kategorija garmonii' $\mathrm{v}$ analizi problem osvity / G.O. Ball // Pedagogichna majsternist' akademika Ivana Zjazjuna: zb. nauk. pr. / [redkol. N.G. Nychkalo (golova), ta in. ; uporjad.: N.G. Nychkalo, O.M. Borovik ; In-t ped. osvity i osvity doroslyh NAPN Ukrai'ny. - K. : Bogdanova A.M., 2013. - S. 114-120.

2. Ball G. Systema pryncypiv raciogumanizmu / Georgij Ball // Psyhologija i suspil'stvo. - 2011. - № 4. - S. 16-32.

3. Varij M. J. Zagal'na psyhologija / M.J Varij: Navchal'nyj posibnyk / 2-ge vydan., vypr. i dop. - K.: «Centr uchbovoi' literatury», 2007. - $968 \mathrm{c}$.

4. Hurlieva T. S. Vysokyj smysl zhyttja jak cinnist' i chynnyk formuvannja strategij psyhologichnoi' dopomogy u vyrishenni ljudynoju ekzystencijnyh problem // Sociokul'turni chynnyky stanovlennja suchasnoi' paradygmy psyhoterapevtychnoi' dopomogy osobystosti: monografija / [Z.G. Kisarchuk, L.O. Grebin', T.S. Gurljeva ta in.] ; za red. Z.G. Kisarchuk. - Kirovograd: Imeks-LTD, 2012. - C. 94118.

5. Zazymko $O$. Formuvannja zhyttjevyh cinnostej u junac'komu vici: psyhologichni osoblyvosti / O. Zazymko // Visn. Kyi'v. nac. torg.-ekon. un-tu. - 2012. - № 4. - S. 89-104.

6. Klymenko $V$. $V$. Struktura psyhofiziologichnyh staniv u profesijnomu zdijsnenni osobystosti / V.V. Klymenko // Psyhofiziologichni zakonomirnosti profesijnogo samozdijsnennja osobystosti : monografija / O.M. Kokun, V.V. Klymenko, O.M. Kornijaka. O.R. Malhazov [ta in.] ; za red.O.M. Kokuna. - R.1.2. - K.: Pedagogichna dumka, 2015. - S. 16-51.

7. Kon I. S. Psyhologija rann'oi' junosti: Kn. dlja vchytelja / I.S. Kon. - M.: Prosveshhenye, 1989 . - 255 s. (Psyhol. nauka - shkoli).

8. Konceptual'ni zasady psyhologo-pedagogichnoi' pidgotovky konkurentozdatnogo fahivcja $\mathrm{v}$ umovah pisljadyplomnoi' pedagogichnoi' osvity : na vybirci naukovo-pedagogichnyh pracivnykiv / avtor.kol. : L.M. Sergejeva, O.I. Bondarchuk, M.I. Skrypnyk, A.O. Molchanova, O.A. Fil'; nauk. red. G.O. Kozlakova. - K. : DVNZ «Un-t menedzh.osvity», 2015. — $40 \mathrm{~s}$.

9. Maksymenko S. D. Osobystist' pochynajet'sja z ljubovi / S. D. Maksymenko // Zagal'na psyhologija : hrestomatija : navch. posib. dlja stud. vyshh. navch. zakl. / uporjad.: O.V. Skrypchenko, L.V. Dolyns'ka, Z.V. Ogorodnijchuk ta in. K. : Karavela, 2007. - S. 428-444.

10. Maslou A. Motivacija i lichnost' / A. Maslou. 3-e izd. SPb.: Piter, 2008. - 352 s. (Serija "Mastera psihologii”).

11. Osichnjuk E. V. Smysl zhizni... V chjom on? / Efim Veniaminovich Osichnjuk. - Kiev: Znanie, USSR, 1987. 47 s. (Serija 2).

12. Pavlyk N. V. Psyhologija garmonizacii' harakteru v junac'komu vici / Natalija Vasylivna Pavlyk. - Dys. d-ra psyhol.nauk : 19.00.07 - pedagogichna ta vikova psyhologija. - Kyi'v, 2017. - 527 s.

13. Pashukova T. I. Izmenenie smyisla zhizni i duhovnoe preobrazovanie cheloveka / Smyisl zhizni i akme : 10 let poiska : V 2 ch. / T I. Pashukova / pod red. A.A. BodalYova, G.A. Vayzer, N.A. Karpovoy, V.E. Chudnovskogo. - M. : Smyisl, 2004. - Chast 2. 224 s.

14. Psihologiya i pedagogika zhittetvorchosti : navch.- metod. posIb. / za red. L.V. Sohan, I.G. Ermakova. - K. : VIPOL, 1996. - $792 \mathrm{~s}$.

15. Psihologiya s chelovecheskim litsom: Gumanisticheskaya perspektiva $\mathrm{v}$ postsovetskoy psihologii / Pod red. D.A. Leonteva, V.G. Schur. - M.: «Smyisl», 1997. — 335 s. - (Fundamentalnaya psihologiya).

16. Roschin D. G. KategorIya «smisl zhittya osobistostI» v sistemI sumIzhnih ponyat gumanItarnih nauk / D.G. Roschin // VIsnik KiYivskogo nats. unIversitetu Im. Tarasa Shevchenka: ser: SotsIologIya . - 2010. - \# 1/2 . S. 94-98.

17. Rubinshteyn S. L. Problemyi obschey psihologii / S.L. Rubinshteyn. - SPb. : Piter Kom, 1999. - 720 s.

18. Rubinshteyn S. L. Chelovek i mir / S.L. Rubinshteyn. M.: Nauka, 1997. - 190 s. 
19. Savchin M. Teoretiko-metodologIchna resursnIst duhovnoYi paradigmi psihologIYi v doslIdzhennI osobistostI / Miroslav Savchin // PsihologIya osobistostI. - 2015. - \# 1 (6). - S. 42-52.

20. Tatenko $V$. A. Predmet i metod psihologicheskoy nauki: sub'ektnaya paradigma / V.A. Tatenko // Predmet i metod psihologii: Antologiya / Pod red. E.B. Starovoytenko. - M.: Akademicheskiy Proekt: Gaudeamus, 2005. - s.490-509.

21. Titarenko T. M. ZhittEviy svIt osobistostI: u mezhah I za mezhami budennostI / T.M. Titarenko. - K. : LibId, 2003. - 374 s.

22. Ushkalov L. Lovitva nevlovnogo ptaha: zhittya GrigorIya Skovorodi / LeonId Ushkalov. - K. : Duh I LItera, 2017. - 368 s. (SerIya «PostatI kulturi»).

23. Frankl V. Chelovek v poiskah smyisla / Viktor Frankl. - M. : Progress, 1990. - 360 s.

24. Chudnovskiy V. E. Rol smyislozhiznennyih orientatsiy i akme $\mathrm{v}$ professionalnoy deyatelnosti (opyit teoretikoeksperiment. issledovaniya / V.E. Chudnovskiy, A.A. Bodalev, G.A. Vayzer, E.E. Vahromov, N.L. Karpova, A.V. Suvorov // Psihologicheskiy zhurnal. 2004. - T. 25, \# 1. - S. 25-30.

\section{Hurlieva Tetiana}

PhD in Psychological Sciences, Senior Research Fellow at the Laboratory of Counseling Psychology and Psychotherapy, H. S. Kostiuk Institute of Psychology of the National Academy of Educational Sciences of Ukraine, Kyiv (Ukraine)

\section{THE RESEARCH OF THE NOTION «HARMONY» IN THE CONTEXT OF PERSONAL VITAL VALUES}

\section{ABSTRACT}

The article considers the concept of harmony in the context of vital personal values, their structure, hierarchy, dynamics, the conditions of moving onto a higher level. The understanding of harmony and harmonization of vital personal values and personal vital functions are presented in the theories of such important scholars as H. O. Bal, O. M. Leontiev, S. D. Maksymenko, A. Maslow, V. A. Petrovskii, S. L. Rubinstein, V. O. Tatenko, V. Frankl, V. E. Chudnovskii and many others.

It is mentioned that in the studies of domestic and foreign scientists the notion of harmony is mostly revarded in the context of personal development, an individual's relationships with other people and with the world. However, this study does not cover the semantic field of personality as a balanced and dynamic whole.

By the harmony of vital values the author of the article implies such a correlation of the parts of semantic sphere that characterizes innerly consistent (taking some possible semantic disharmony into account) existence of vital personal values on a certain stage of their formation as a corporal, social and spiritual entity. The focus is on sublime, essential and spiritual values which enable the harmony of the personal semantic sphere, balance and streamline human needs and ensure a bottom-up vector of their development. The results of the scientific research as well as personal presumptions allow to ascertain the presence of harmony in relative disharmony of formed vital values, which in their connection and interrelation enhance successful personal development. An explanation is given of constructive and destructive semantic disharmonies. The article highlights the importance of harmoniza- 
tion of vital values in adolescence and youth.

From the position of humanistic psychology, the perspectives of psychological assistance in harmonizing vital values are outlined. It is considered that it is a dialogue and dialogue-like communication which are the conditions to a person seeking and revealing their meaning of life and harmonizing their personal sphere of values. This communication occurs mainly between a psychologist and client, seeking psychological assistance in case of the loss of meaning of life or disorientation in this sphere.

Key words: harmony, personal sphere of values, the harmony of vital values, semantic disharmony, bottom-up personal development, subject, harmonization, humanism, dialogue.

\section{Гурлева Татьяна Степановна}

Кандидат психологических наук, стариий научный сотрудник лаборатории консультативной психологии $u$ психотерапии Института психологии имени Г.С. Костюка Национальной академии педагогических наук Украинь, г. Киев (Украина)

\section{ИССЛЕДОВАНИЕ ПОНЯТИЯ «ГАРМОНИЯ» В АСПЕКТЕ ЖИЗНЕННЫХ СМЫСЛОВ ЛИЧНОСТИ}

Аннотация. В статье рассматривается понятие «гармония» в аспекте жизненных смыслов личности, их структуры, иерархии, динамики, условий восхождения на более высокий уровень. Представлено понимание гармонии и гармонизации жизненных смыслов личности и ее жизнедеятельности в теориях таких известных ученых, как Г. А. Балл,
А. Н. Леонтьев, С. Д. Максименко, А. Маслоу, В. А. Петровский, С. Л. Рубинштейн, В. А. Татенко, В. Франкл, В. Э. Чудновский и многих других.

Отмечено, что в научных исследованияХ понятие гармония в основном рассматривается в контексте развития личности вообще, ее отношений с другими людьми, с миром, однако не охвачено смысловое поле личности как уравновешенное и динамическое целое.

Под «гармонией жизненных смыслов» личтости автор статьи понимает такое соотношение частей смысловой сферы, которое характеризует внутренне непротиворечивое, учитывая возможные «смысловые дисгармонии», существование жизненных смыслов человека на определенном этапе его становления как телесного, социального, духовного существа.

Акцентировано внимание на высоких, сущностных, духовных смыслах, которые обеспечивают гармонию жизненных смыслов, уравновешивают, упорядочивают потребности человека, обеспечивают восходящий вектор их развития. Результаты научного поиска и собственные предположения дают возможность констатировать присутствие гармонии в относительной дисгармоничности сформированных жизненных смыслов, которые в своей связи и взаимовлиянии способствуют благополучному развитию личности. Дается пояснение конструктивных и деструктивных смысловых дисгармоний. Подчеркивается зна- 
чение гармонизации жизненных смыслов в подростковом и юношеском возрасте.

С позиций гуманистической психологии очерчены перспективы гармонизации жизненных смыслов личности в процессе психологической помощи. Утверждается, что условием осознания, поиска и открытия человеком смысла жизни и гармонизации смисложизненной сферы личности является диалог, диалогическое общение между людьми, в частности между психологом и клиентом, который нуждается в психологической помощи в случае утраты смысла существования, смысложизненной дезориентации и т.п.

Ключевые слова: гармония, смысловая сфера личности, гармония жизненных смыслов, смысловая дисгармония, личностное развитие по восходящей, субъект, гармонизация, гуманизм, диалог. 